\title{
Influence of wet vs. dry by-product ingredients and addition of branched-chain volatile fatty acids and valerate to dairy diets. 3. Kinetics of rumen ingesta turnover, whole tract digestibility, and some plasma hormone concentrations
}

\author{
P. H. Robinson*, S. Tamminga and A. M. van Vuuren
}

Institute for Livestock Feeding and Nutrition Research (IVVO), P.O. Box 160, NL 8200 AD Lelystad, Netherlands

Received 8 October 1986; accepted 20 March 1987

Key words: isoacids, valerate, dairy, rumen, kinetics, somatotropin, insulin

\begin{abstract}
Four dairy cows with large rumen cannulae were fed totally mixed diets twice daily. Diets contained equal amounts of hay crop silage and maize silage to a total of about $43 \%$ of dry matter (DM) intake. About $35 \%$ of DM intake was derived from the by-product ingredients maize gluten feed, beet pulp, and brewers' grains; the balance was mixed ingredients. Diets were formulated to contain either wet ensiled (WET) or dry (DRY) by-product ingredients without (MINUS) or with (PLUS) a supplement (ISOPLUS ${ }^{\mathrm{TM}}$ ) containing the branched-chain volatile fatty acids (isoacids) isobutyrate, 2-methyl butyrate, and 3-methyl butyrate, as well as valerate. Measurements were made from weeks 12 to 28 of lactation to determine effects of treatments on whole tract digestibility, kinetics of rumen ingesta turnover, as well as plasma concentrations of insulin and somatotropin.

Whole tract apparent digestibility of organic matter (OM) and most OM components was either higher $(P<0.05)$ or tended $(P<0.10)$ to be higher with WET diets. Estimated true digestion of dietary $\mathrm{N}$ and OM were also higher $(P<0.05)$ with WET diets but the extent was less pronounced than for apparent digestibility, and differences were small. Whole tract digestibility of OM components were not influenced by supplementation with ISOPLUS ${ }^{\mathrm{TM}}$. Rumen bacterial OM pool was larger $(P<0.05)$ and rumen bacterial $\mathrm{N}$ pool tended $(P<0.10)$ to be larger with DRY diets but this was not reflected by increased rate of rumen digestion of neutral detergent (ND) fibre. Rumen pool sizes of $\mathrm{N}$ and $\mathrm{OM}$ components were not influ-

* Current address: Department of Animal Science, University of Alberta, Edmonton, Alberta T6G 2P5, Canada.
\end{abstract}


enced by addition of ISOPLUS ${ }^{\mathrm{TM}}$. Rates of rumen digestion and passage of ND fibre were not influenced by diet form or addition of ISOPLUS ${ }^{\mathrm{TM}}$. There was no influence of diet form or supplementation with ISOPLUS ${ }^{\mathrm{TM}}$ on plasma concentrations of insulin or somatotropin.

\section{Introduction}

Branched-chain volatile fatty acids (isoacids) are either required by, or stimulate the growth of many rumen bacterial species, particularly those that ferment cellulose (Bryant, 1973). Russell \& Sniffen (1984) demonstrated differences in isoacid requirements of cellulolytic and non-cellulolytic bacteria when they showed that bacteria isolated from the rumen of a cow fed a $60 \%$ concentrate diet did not respond to isoacid addition whereas rumen bacteria isolated from the same cow fed an all-hay diet responded with increased bacterial protein synthesis. Stimulatory acids are not the same in all studies. In the study of Russell \& Sniffen (1984), bacterial protein synthesis was stimulated with 2-and 3-methyl butyrate but not isobutyrate or valerate alone. Bentley et al. (1955) found that valerate, caproate, isobutyrate, and 3-methyl butyrate increased rate of cellulose digestion in vitro. Gorosito et al. (1985) stimulated rate of in vitro digestion of cell wall, isolated from several feedstuffs, by addition of isobutyrate, 2- or 3-methyl butyrate, but valerate was without effect. Stern et al. (1985) demonstrated increased neutral detergent (ND) fibre digestion in vitro with addition of isobutyrate and 2- and 3-methyl butyrate. It seems clear that bacterial protein synthesis and/or fibre digestion can be stimulated in vitro with addition of various combinations of isoacids and valerate. Improved digestibility of dry matter (DM) and/or ND fibre components due to isoacid addition has been reported for cattle fed straw-urea diets (Hemsley et al., 1963; Cline et al., 1966), although this is not always the case (Umunna et al., 1975). Production responses to dietary addition of isoacids and valerate have also been recorded in dairy cattle, mostly with diets in which part of the dietary nitrogen $(\mathrm{N})$ was from urea (Papas et al., 1984; Pierce-Sandner et al., 1985). Evidence for a stimulatory effect on digestion in vivo as a mechanism whereby increased production occurs on diets containing protein is however not available. Indeed available information suggests that addition of mixtures of isoacids and valerate to practical dairy diets has no influence on apparent digestion of DM and N (Felix et al., 1980; Fieo et al., 1984) or acid detergent (AD) fibre (Fieo et al., 1984). However in neither of these studies was isoacid supplementation associated with increased productivity. It may be that isoacids, or their constituent amino acids, have a beneficial influence on intermediary metabolism, possibly by stimulating production of somatotropin (Fieo et al., 1984; Brondani \& Cook, 1985). Exogenous somatotropin supplementation has been shown to stimulate milk production in dairy cows (Peel et al., 1983) and it is possible that at least a part of the production response as a result of the addition of isoacids observed in dairy cattle fed practical diets is by an extra-ruminal mechanism.

Fermentation of feeds during ensiling decreases levels of protein $\mathrm{N}$ and increases levels of ammonia and free amino acids which are rapidly fermented in the rumen 
(MacDonald, 1982). If ensiled forages are supplemented with ensiled by-product ingredients, it is possible that levels of branched-chain amino acids in dietary protein will be low enough to cause a deficiency of slowly released branched chain carbon skeletons for rumen bacterial growth.

The objectives of this study were to determine:

1) if replacement of dry by-product ingredients with wet ensiled by-product ingredients in the diet of dairy cows modifies digestibility of dietary components, rumen pool sizes of $\mathrm{N}$ and organic matter (OM) components, kinetics of ND fibre digestion and passage from the rumen, and plasma concentrations of somatotropin and insulin, and

2) if supplementation with isoacids plus valerate (ISOPLUS ${ }^{\mathrm{TM}}$; Eastman Chemicals, Kingsport, TN, USA) influences these parameters differently in the two diets. The preceding paper in this series (Robinson et al., 1987b) reported parameters of rumen fermentation as well as milk production and composition. This study was completed concurrent with a production study utilizing 56 lactating dairy cows (de Visser \& Tamminga, 1987).

\section{Experimental methods}

The design of the experiment, basal rations, treatments, experimental periods, and statistical analysis have been described in detail in the previous papers in this series (de Visser \& Tamminga, 1987; Robinson et al., 1987b). Four Friesian dairy cows were utilized in a $2 \times 2$ factorial arrangement of treatments with two forms of the diet, wet by-product ingredients (WET) or dry by-product ingredients (DRY), either with (PLUS) or without (MINUS) a commercial supplement of isoacids and valerate (ISOPLUS ${ }^{\mathrm{TM}}$ ). Periods were 28 days in duration and the first period started approximately 12 weeks post-partum.

Digestibility trials were carried out over the 72-h period from $09 \mathrm{~h} 00$ on day 21 of each period. Faecal collection was semi-quantitative and therefore faecal DM flow was corrected for incomplete marker recovery. The marker used was chromium (Cr) mordanted straw ND fibre and its recovery averaged $89.7 \pm 8.8 \%$. Faecal bacteria were isolated by differential centrifugation. Based on the chemical composition, and the diaminopimelic acid concentration, of isolated faecal bacteria, faecal $\mathrm{OM}$ and $\mathrm{N}$ was separated, by calculation, into bacterial and non-bacterial fractions. A more detailed description of the procedures involved is given elsewhere (Robinson et al., 1987a).

Rumen ingesta mass and composition were estimated by manual evacuation on three occasions per period at $21 \mathrm{~h} 00$ on day $24,11 \mathrm{~h} 00$ on day 25 , and $01 \mathrm{~h} 00$ on day 26 by procedures described elsewhere (Robinson et al., 1987c). Kinetics of rumen ND fibre intake, passage, and digestion were calculated as:

- rate of intake $\left(k_{\mathrm{i}}\right)=100$ (ND fibre intake, $\left.\mathrm{kg} / \mathrm{d}\right) /(\mathrm{ND}$ fibre pool, $\mathrm{kg}$ )

- rate of passage $\left(k_{\mathrm{p}}\right)=100$ (faecal ND fibre flow, $\left.\mathrm{kg} / \mathrm{d} / 0.85\right) /(\mathrm{ND}$ fibre pool, $\mathrm{kg}$ )

- rate of digestion $\left(k_{\mathrm{s}}\right)=k_{\mathrm{i}}-k_{\mathrm{p}}$

In sacco rumen DM disappearance from WET and DRY brewers' grains, maize gluten feed, beet pulp, forages, and the concentrates were estimated in each cow 
between experimental Periods 2 and 3 when cows were fed the midpoint diet (half WET and half DRY diets with half the level of ISOPLUS ${ }^{\mathrm{TM}}$ added to PLUS diets). The procedure used was similar to that described by Robinson et al. (1986a). Times of incubation were $0,6,12,18,24$, and $48 \mathrm{~h}$. Upon removal from the rumen, bags were rinsed in a washing machine at $20^{\circ} \mathrm{C}$ and dried at $60^{\circ} \mathrm{C}$. Disappearance of DM from bags was described by a logistic model similar to that used by Robinson et al. (1986a):

$$
\mathrm{DMR}=S \cdot \exp (-\infty \mathrm{t})+\mathrm{D} /(p \cdot \exp (\mathrm{kt})+(1-\mathrm{p}))+\mathrm{U}
$$

where:

$\mathrm{DMR}=$ residual DM (\% of total DM)

$\mathrm{S}=$ size of soluble DM fraction (\% of total DM)

$\mathrm{D}=$ size of degradable DM fraction (\% of total DM)

$\mathrm{U}=$ size of undegradable DM fraction (\% of total DM)

$k=$ rate constant for degradation of DM incorporating rate of DM degradation and rate of bacterial growth $\left(\mathrm{h}^{-1}\right)$

$p=$ dimentionless parameter incorporating rate of bacterial growth and the size of the degradable DM fraction

Samples of blood were collected by jugular puncture on six occasions per cow on Days 27 and 28 of each period. Times of collection were $14 \mathrm{~h} 30,17 \mathrm{~h} 00,24 \mathrm{~h} 00,05$ h $30,08 \mathrm{~h} 00$, and $12 \mathrm{~h} 00 \pm 15 \mathrm{~min}$. Samples were collected to heparinized Vacutainers $^{\mathrm{TM}}$ (Becton-Dickinson \& Co., Rutherford, NJ, USA), centrifuged immediately, and plasma frozen for later assay. Samples were assayed commercially for insulin and somatotropin (Bergschot Centrum voor Onderzoek/Analytical Services b.v., Bergschot 69,4817 PA Breda, Netherlands). Insulin was assayed by a kit supplied by Immuno Nuclear Corporation ('Insulin by RIA', Catalogue No 0600). For analysis of somatotropin a pure bovine growth hormone (bGH) preparation was labelled with $\mathrm{Na}$ J-125 lactoperoxidase, and hydrogen peroxide. Immediately before each determination series the label was cleared on Sephadex G100 and diluted to $\pm 150000 \mathrm{cpm} / \mu \mathrm{l}$. Samples and standard were incubated for $24 \mathrm{~h}$ with anti-serum. After adding the label the material was incubated for another $40 \mathrm{~h}$ after which free and bound hormone were separated with double-antibody-solid-phase (DSAP).

Other analytical procedures have been described (Robinson et al., 1986b; 1987a).

\section{Results}

\section{Intake and digestion}

Intake of DM, OM, and its components are in Table 1. Intake levels attained in this study were slightly lower than anticipated and about $15 \%$ lower than those achieved in the production study for weeks 12 to 18 of lactation (de Visser \& Tamminga, 1987). Statistically significant differences in intake of dietary DM and OM components do not reflect differences in voluntary intake, but differences in the 
Table 1. Feed intake and apparent whole tract digestibility.

\begin{tabular}{|c|c|c|c|c|c|}
\hline & \multicolumn{2}{|l|}{ DRY } & \multicolumn{2}{|l|}{ WET } & \multirow[t]{2}{*}{ SE } \\
\hline & MINUS & PLUS & MINUS & PLUS & \\
\hline \multicolumn{6}{|l|}{ Dry matter } \\
\hline intake, $\mathrm{kg} / \mathrm{d}^{\mathrm{acl}}$ & $16.93^{\mathrm{d} 2}$ & $17.97^{\mathrm{e}}$ & $17.26^{\mathrm{d}}$ & $16.67^{\mathrm{e}}$ & 0.13 \\
\hline digestion, $\%$ & 64.65 & 64.89 & 67.53 & 67.10 & 1.64 \\
\hline \multicolumn{6}{|l|}{ Organic matter } \\
\hline intake, $\mathrm{kg} / \mathrm{d}^{\mathrm{ac}}$ & $15.20^{\mathrm{d}}$ & $16.24^{\mathrm{e}}$ & $15.55^{\mathrm{d}}$ & $14.95^{\mathrm{e}}$ & 0.11 \\
\hline digestion, $\%^{\text {a }}$ & 67.23 & 66.99 & 70.73 & 70.33 & 1.67 \\
\hline \multicolumn{6}{|l|}{ ND fibre } \\
\hline intake, $\mathrm{kg} / \mathrm{d}$ & 7.26 & 6.99 & 7.42 & 7.06 & 0.25 \\
\hline digestion, $\%$ & 60.30 & 56.23 & 62.80 & 61.08 & 3.16 \\
\hline \multicolumn{6}{|l|}{ AD fibre } \\
\hline intake, $\mathrm{kg} / \mathrm{d}$ & 3.83 & 3.72 & 3.92 & 3.80 & 0.21 \\
\hline digestion, $\%$ & 57.05 & 52.60 & 59.95 & 60.15 & 3.84 \\
\hline \multicolumn{6}{|l|}{ Starch } \\
\hline intake, $\mathrm{kg} / \mathrm{d}^{\mathrm{b}}$ & 1.38 & 1.64 & 1.49 & 1.59 & 0.12 \\
\hline digestion, $\%$ & 95.25 & 94.95 & 95.35 & 96.55 & 1.74 \\
\hline \multicolumn{6}{|l|}{ Nitrogen } \\
\hline intake, $\mathrm{g} / \mathrm{d}^{\mathrm{c}}$ & $0.49^{\mathrm{d}}$ & $0.55^{\mathrm{e}}$ & $0.53^{\mathrm{d}}$ & $0.50^{\mathrm{e}}$ & 0.01 \\
\hline digestion, $\%^{\mathrm{a}}$ & 62.74 & 59.98 & 67.08 & 68.41 & 2.22 \\
\hline \multicolumn{6}{|l|}{ Crude fat } \\
\hline intake, $\mathrm{kg} / \mathrm{d}$ & 0.78 & 0.67 & 0.80 & 0.74 & 0.07 \\
\hline digestion, $\%$ & 81.28 & 73.39 & 80.79 & 83.00 & 5.55 \\
\hline
\end{tabular}

1 a: significant $(P<0.05)$ difference due to form of the diet; b: significant $(P<0.05)$ difference due to isoacids; $c$ : significant $(P<0.05)$ form $\times$ isoacid interaction.

${ }^{2}$ Means within WET or DRY with different superscripts differ $(P<0.05)$.

amount of feed offered (see Robinson et al., 1987b).

Digestibilities of dietary components (Table 1) are similar to values for dairy cows fed at comparable levels of intake (Tamminga et al., 1979; Robinson \& Sniffen, 1985; Robinson et al., 1987a). Digestibility of OM and N was lower with DRY diets and digestibility of DM and AD fibre tended $(P<0.10)$ to be lower.

\section{Faecal nitrogen and organic matter fractions and flows}

Composition of faecal bacteria (Table 2) are comparable to those reported for other dairy cows (Robinson et al., 1987a). Total N content of bacteria was higher for bacteria from faeces of cows fed DRY diets.

Faecal $\mathrm{N}$ and $\mathrm{OM}$ fractions and flows are in Table 3. Faecal $\mathrm{N}$ and non-ammonia $\mathrm{N}$ (NAN) excretion was greater with DRY diets. Faecal residual $\mathrm{N}$ was greater with DRY diets both as $\mathrm{g} / \mathrm{d}$ and as a proportion of $\mathrm{N}$ intake. Faecal OM excretion was greater for DRY diets and ND fibre excretion tended $(P<0.10)$ to be greater. Residual faecal OM was greater for DRY diets both as $\mathrm{kg} / \mathrm{d}$ and as a proportion of ND solubles intake. 
Table 2. Bacteria composition.

\begin{tabular}{|c|c|c|c|c|c|}
\hline & \multicolumn{2}{|l|}{ DRY } & \multicolumn{2}{|l|}{ WET } & \multirow[t]{2}{*}{$\mathrm{SE}$} \\
\hline & MINUS & PLUS & MINUS & PLUS & \\
\hline \multicolumn{6}{|l|}{ Faecal bacteria } \\
\hline DAPA, $\mu \mathrm{g} / \mathrm{g}$ OM & 4.83 & 4.58 & 3.47 & 4.91 & 0.75 \\
\hline N/DAPA, g/mmol & 3.44 & 3.68 & 4.39 & 3.27 & 0.58 \\
\hline \multicolumn{6}{|l|}{ Rumen bacteria } \\
\hline $\begin{array}{l}\text { total } \mathrm{N}, \mathrm{mg} / \mathrm{g} \text { OM } \\
\text { DAPA } \mu \mathrm{g} / \mathrm{g} \text { OM }\end{array}$ & $\begin{array}{l}90.8 \\
4.20\end{array}$ & $\begin{array}{c}88.4 \\
4.24\end{array}$ & $\begin{array}{c}93.8 \\
4.05\end{array}$ & $\begin{array}{c}93.9 \\
4.32\end{array}$ & $\begin{array}{l}7.3 \\
0.36\end{array}$ \\
\hline N/DAPA, g/mmol & 4.10 & 4.00 & 4.40 & 4.15 & 0.19 \\
\hline
\end{tabular}

1 Significant $(P<0.05)$ difference due to form of the diet.

Table 3. Faecal nitrogen and organic matter fractions and flows.

\begin{tabular}{llll}
\hline DRY & & WET & \\
MINUS & PLUS & MINUS & PLUS
\end{tabular}

Faecal nitrogen components

Total

$\%$ dry matter ${ }^{\mathrm{a}}$

excretion, $g / d^{a}$

Non-ammonia

excretion, $\mathrm{g} / \mathrm{d}^{\mathrm{a}}$

$\%$ of N intake

Bacterial

excretion, g/d

$\%$ of faecal NAN

Residual

excretion, $g / d^{a}$

$\%$ of $\mathrm{N}$ intake

$\begin{array}{rrrrr}3.31 & 3.28 & 3.00 & 2.95 & 16 \\ 198 & 208 & 168 & 163 & 7 \\ 183 & 193 & 154 & 150 & 9 \\ 37.1 & 34.7 & 28.9 & 30.3 & 2.3 \\ 107 & 104 & 97 & 79 & 15 \\ 58.9 & 55.1 & 63.5 & 53.7 & 6.7 \\ 90 & 92 & 53 & 71 & 22 \\ 15.2 & 15.9 & 10.5 & 14.4 & 1.7\end{array}$

Faecal organic matter components

Total

$\%$ dry matter ${ }^{\mathrm{a}}$

excretion, $\mathrm{kg} / \mathrm{d}^{\mathrm{a}}$

ND fibre

excretion, $\mathrm{kg} / \mathrm{d}$

$\%$ faecal OM $^{\mathrm{a}}$

Bacterial

excretion, $\mathrm{kg} / \mathrm{d}$

$\%$ of faecal OM

Residual

excretion, $\mathrm{kg} / \mathrm{d}^{\mathrm{a}}$

$\%$ of ND solubles intake
83.

5.00

2.89

57.8

1.28

25.9

0.82

10.2
84.9

5.37

3.08

57.3

$1.19 \quad 1.18$

$22.4 \quad 25.8$

1.10

11.8
0.63

7.8

81.2

4.55

2.75

60.4

1.18
5.8

1.00

22.6

0.70

9.0

80.9

4.45

2.75
0.9

0.26

0.16

1.6

${ }^{1}$ Significant $(P<0.05)$ difference due to form of the diet.
SE

15

22 
Table 4. Total rumen contents.

\begin{tabular}{|c|c|c|c|c|c|}
\hline & \multicolumn{2}{|l|}{ DRY } & \multicolumn{2}{|l|}{ WET } & \multirow[t]{2}{*}{ SE } \\
\hline & MINUS & PLUS & MINUS & PLUS & \\
\hline Non-dry matter, kg & 69.6 & 69.9 & 69.3 & 67.6 & 4.6 \\
\hline Dry matter, $\mathrm{kg}$ & 9.73 & 9.78 & 10.28 & 9.73 & 0.60 \\
\hline Percentage DM & 12.3 & 12.3 & 12.9 & 12.5 & 0.4 \\
\hline $\mathrm{Mat}^{1.2}, \mathrm{~kg}$ & 74.1 & 63.4 & 66.9 & 70.3 & 8.1 \\
\hline Bailable liquids ${ }^{3.2}, \mathrm{~kg}$ & 11.9 & 12.1 & 8.4 & 8.7 & 3.2 \\
\hline Percentage mat & 85.0 & 84.7 & 89.2 & 87.7 & 4.5 \\
\hline Total ingesta ${ }^{4}, \mathrm{~kg}$ & 79.3 & 80.0 & 79.5 & 77.3 & 5.1 \\
\hline
\end{tabular}

${ }_{1}$ Mat is wet particulate material which could be removed from the rumen by hand.

${ }^{2}$ Non-dry matter plus dry matter or mat plus bailable liquid may not equal total ingesta due to least squares missing value estimation.

${ }^{3}$ Bailable liquid is liquid material remaining in the rumen after the hand removal of mat that was removed with a 1 -litre plastic cup.

${ }^{4}$ Defined in text.

Table 5. Rumen pool sizes of nitrogen and organic matter components.

\begin{tabular}{|c|c|c|c|c|c|}
\hline & \multicolumn{2}{|l|}{ DRY } & \multicolumn{2}{|l|}{ WET } & \multirow[t]{2}{*}{ SE } \\
\hline & MINUS & PLUS & MINUS & PLUS & \\
\hline \multicolumn{6}{|l|}{ Rumen N pool sizes } \\
\hline Total NAN, $\mathrm{g}$ & 359 & 368 & 355 & 338 & 17 \\
\hline \multicolumn{6}{|l|}{ Bacterial } \\
\hline total, $\mathrm{g}$ & 163 & 177 & 156 & 135 & 20 \\
\hline$\%$ of rumen NAN & 47.8 & 45.1 & 39.6 & 43.8 & 4.1 \\
\hline \multicolumn{6}{|l|}{ Residual } \\
\hline$\%$ of $\mathrm{N}$ intake $\mathrm{e}^{1,2}$ & $39.9^{\mathrm{b}}$ & $34.3^{\mathrm{c}}$ & $37.4^{\mathrm{b}}$ & $\begin{array}{r}204 \\
41.0^{c}\end{array}$ & 2.2 \\
\hline \multicolumn{6}{|l|}{ Rumen OM pool sizes } \\
\hline $\begin{array}{l}\mathrm{kg} \\
\text { ND fibre }\end{array}$ & 8.56 & 8.71 & 9.14 & 8.63 & 0.54 \\
\hline $\mathrm{kg}$ & 4.97 & 5.00 & 5.27 & 5.11 & 0.51 \\
\hline$\%$ rumen $\mathrm{OM}$ & 57.9 & 57.5 & 57.8 & 58.6 & 2.4 \\
\hline \multicolumn{6}{|l|}{ Bacterial } \\
\hline $\begin{array}{l}\mathrm{kg}^{2} \\
\% \text { rumen } \mathrm{OM}^{2}\end{array}$ & 1.83 & 2.01 & 1.66 & 1.45 & 0.17 \\
\hline \multicolumn{4}{|l|}{ Residual } & & 1.3 \\
\hline $\mathrm{kg}^{\mathrm{d}}$ & 1.77 & 1.71 & 2.21 & 2.07 & 0.15 \\
\hline$\%$ ND solubles intake & 21.6 & 18.8 & 27.4 & 27.2 & 2.0 \\
\hline
\end{tabular}

\footnotetext{
1 Significant $(P<0.05)$ form $\times$ isoacid interaction.

2 Means within WET or DRY with different superscripts differ.

${ }^{3}$ Significant $(P<0.05)$ difference due to form of the diet.
} 
Table 6. Kinetic parameters for ND fibre calculated from evacuation data.

\begin{tabular}{|c|c|c|c|c|c|}
\hline & \multicolumn{2}{|l|}{ DRY } & \multicolumn{2}{|l|}{ WET } & \multirow[t]{2}{*}{ SE } \\
\hline & MINUS & PLUS & MINUS & PLUS & \\
\hline \multicolumn{6}{|l|}{ ND fibre flows } \\
\hline faecal, $\mathrm{kg} / \mathrm{d}$ & 2.89 & 3.08 & 2.75 & 2.75 & 0.16 \\
\hline duodenal, $\mathrm{kg} / \mathrm{d}^{\mathrm{t}}$ & 3.40 & 3.62 & 3.24 & 3.24 & \\
\hline \multicolumn{6}{|c|}{ ND fibre rates (\%/day) } \\
\hline$k_{\text {intake }}$ & 148 & 141 & 141 & 144 & 10 \\
\hline$k_{\text {passage }}$ & 69 & 73 & 62 & 66 & 8 \\
\hline$k_{\text {digestion }}^{\text {passege }} 2$ & 79 & 69 & 80 & 79 & 7 \\
\hline
\end{tabular}

${ }^{1}$ Faecal flow/0.85 (see text for rationale).

2 Calculated by difference $\left(k_{\text {intake }}-k_{\text {passage }}\right)$.

Table 7. Parameters of the model ${ }^{1}$ used to describe in sacco rumen degradation of dry matter from WET and DRY by-product ingredients ${ }^{2}$.

\begin{tabular}{lccl}
\hline Form of the diet & DRY & WET & SE \\
& & & \\
Soluble, \% of $\mathrm{DM}^{3}$ & 23.3 & 26.2 & 2.1 \\
Degradable, \% of DM & 54.6 & 52.3 & 2.6 \\
Undegradable, \% of DM & 22.0 & 20.2 & 2.8 \\
& & & \\
$k^{\dagger}, \% / \mathrm{h}$ & 10.7 & 11.2 & 3.7 \\
$p$ & 0.55 & 0.47 & 0.28 \\
\hline
\end{tabular}

Model described in text.

2 Brewers' grains, maize gluten feed, beet pulp.

${ }^{3}$ Significant difference due to form of the diet $(P<0.05)$.

${ }^{4}$ For degradable fraction.

Table 8. Plasma hormone concentrations.

\begin{tabular}{lcccccc}
\hline & \multicolumn{2}{l}{ DRY } & & \multicolumn{2}{l}{ WET } & SE \\
\cline { 2 - 3 } & MINUS & PLUS & & MINUS & PLUS & \\
Insulin, $\mu \mathrm{U} / \mathrm{ml}$ & 14.0 & 16.1 & & 15.4 & 16.0 & 1.9 \\
Somatotropin $\mathrm{ng} / \mathrm{ml}$ & 3.4 & 3.1 & 3.3 & 3.4 & 0.4 \\
\hline
\end{tabular}


Rumen pool sizes of DM, non-DM, mat, and bailable liquids are in Table 4. Mat was defined as material removable from the rumen by hand whereas bailable liquids was the residue which had to be bailed out with a small pail (see Robinson et al., 1987a for details of the evacuation procedure). Values are comparable to those previously reported for dairy cows at similar levels of feed intake determined by the evacuation procedure (Hartnell et al., 1979; Shaver et al., 1985; Robinson et al., $1987 \mathrm{c}$ ). Total rumen contents were not influenced by form of the diet or addition of ISOPLUS $^{\mathrm{TM}}$.

Composition of rumen bacteria is in Table 2. Total N, DAPA, and N/DAPA were not influenced by form of the diet or addition of ISOPLUS ${ }^{T M}$.

Rumen pool sizes of $\mathrm{N}$ and $\mathrm{OM}$ components are in Table 5. Rumen bacterial $\mathrm{OM}$ pool size was greater with DRY diets and bacterial $N$ pool size tended $(P<0.10)$ to be greater. Residual OM pool size, both as $\mathrm{kg}$ and as a proportion of ND solubles intake, was smaller with DRY diets. Residual $\mathrm{N}$ pool size as a proportion of $\mathrm{N}$ intake was greater without ISOPLUS ${ }^{\mathrm{TM}}$ addition within DRY diets but greater with ISOPLUS $^{\text {TM }}$ within WET diets.

\section{Kinetics of ND fibre flow}

Duodenal ND fibre flow was estimated as faecal ND fibre flow/0.85. The rationale for this estimate has been discussed elsewhere (Robinson et al., 1987c). Rate constants for ND fibre intake $\left(k_{\mathrm{i}}\right)$, passage $\left(k_{\mathrm{p}}\right)$, and digestion $\left(k_{\mathrm{s}}\right)$ are similar to those reported for dairy cows at similar levels of intake (Robinson et al., 1987c) and were not influenced by either treatment (Table 6).

Use of a first order model with lag (described by Robinson et al., 1986a) to describe loss of DM from nylon bags incubated in the rumen resulted in solutions with bias. This confirmed previous work in our laboratory (van Noort, unpublished); work which also suggested a logistic model (described by Robinson et al., 1986a) consistently described DM disappearance free of bias. DM fraction sizes and rate constants for degradation of the degradable fraction is in Table 7. WET ingredients had a larger soluble fraction and tended $(P<0.10)$ to have a smaller degradable fraction. However differences were small.

\section{Plasma parameters}

Results of plasma hormone assays are in Table 8. There was no influence of form of the diet or addition of ISOPLUS ${ }^{\mathrm{TM}}$ on plasma concentrations of insulin or somatotropin. Insulin values are comparable to those reported by Hart et al. (1980) for British Friesians, but somatotropin values are somewhat lower, perhaps reflecting the higher productivity of cows in our study. Our results (Fig. 1) confirm the influence of stage of lactation on plasma somatotropin concentrations reported by Hart et al. (1980). 


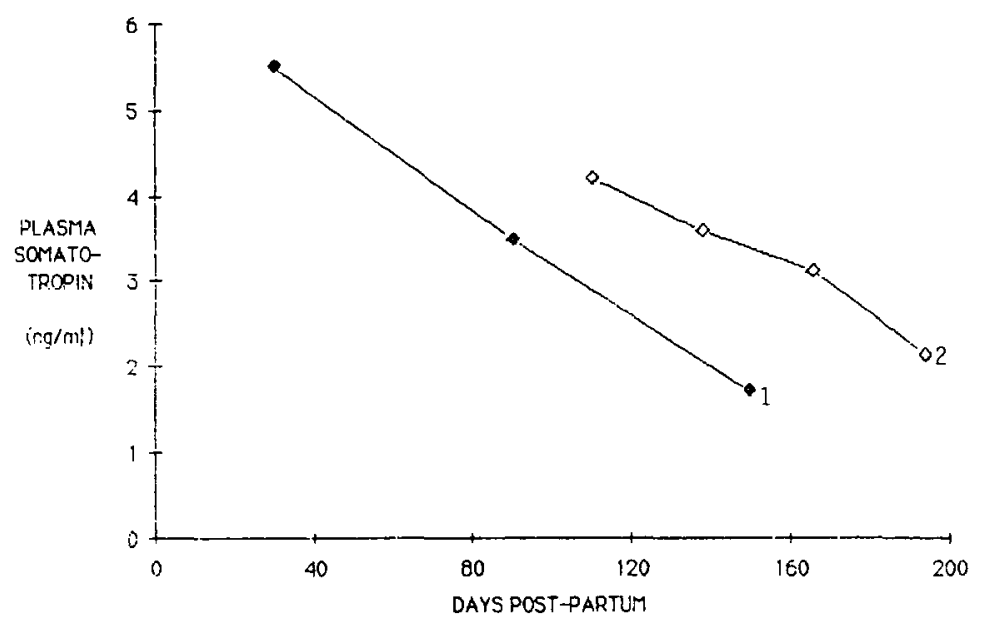

Fig. 1. Influence of stage of lactation on plasma somatotropin levels. 1: Hart et al. (1980); 2 ; this study.

\section{Discussion}

The increase, or tendency to an increase, in apparent digestibility of most dietary OM constituents suggests a higher feeding value of WET diets. This is consistent with results reported by Firkins et al. (1984) for steers and Firkins et al. (1985) for sheep that indicated a tendency to increased digestibility of DM and ND fibre with wet vs. dry maize gluten feed. However the increase in digestibility observed here did not result in higher milk production (de Visser \& Tamminga, 1987; Robinson et al., 1987b), because DM intake was lower for WET diets. Why the apparent digestibility differed between WET and DRY diets remains obscure. Results of de Visser \& Tamminga (1987) showed that in wethers, fed at maintenance, dry maize gluten feed was digested to a lesser extent than wet maize gluten feed, but that dry brewers' grains were digested better than wet brewers' grains. In the mixed concentrate the observed differences would roughly compensate. Results in Table 7 show that the undegradable DM was about $9 \%$ higher for the DRY diet, whereas the rate of degradation of DM was about $5 \%$ lower. Table 6 shows that the rate of passage of cell wall components was also slightly higher, about $10 \%$, with the DRY diet. Although none of these individual parameters differed significantly between WET and DRY diets, in combination they could account for a difference in apparent digestion of 3 to 4 percentage units and become statistically significant. With respect to $\mathrm{N}$ the difference may have become even more pronounced because of a higher microbial $\mathrm{N}$ synthesis in the rumen for cows fed DRY diets. This would result in more $\mathrm{N}$-containing microbial debris being excreted in the faeces, causing the apparent digestion of $\mathbf{N}$ to become even lower.

In another communication (Robinson et al., 1987c) we observed that within a 
single diet, over a wide range of intake levels, there was a strong positive relationship between rate of ND fibre digestion in the rumen $\left(k_{\mathrm{s}}\right)$ and the proportion:

\section{rumen bacterial OM pool size $(\mathrm{kg}) / \mathrm{rumen}$ ND fibre OM pool size $(\mathrm{kg})$}

Such a relationship did not occur here. Indeed the treatment combination with the lowest $k_{\mathrm{s}}$ was associated with the highest proportion of rumen bacterial OM to rumen ND fibre OM.

Reduction in residual $\mathrm{OM}$ and $\mathrm{N}$ pool size cannot be interpreted as a reduced pool size of dietary ND solubles since protozoal OM pool size, which would be included in residual $\mathrm{N}$ or OM, may have been influenced by diet changes (Meyer et al., 1985).

Dietary crude protein levels in diets used in this study exceeded $18 \%$ of DM. In a previous paper in this series (Robinson et al., 1987b) we speculated that due of these high protein levels, concentrations of isoacids in rumen fluid were high enough on unsupplemented diets, presumably from degradation of dietary branch chain amino acids, to prevent deficiency of branched chain carbon skeletons for bacterial growth. Thus dietary addition of isoacids simply increased rumen concentrations of these acids and no statistically, or biologically, significant impact on whole tract digestibility of OM constituents, kinetics of ND fibre digestion and passage from the rumen, or rumen pool sizes of bacterial OM and $\mathrm{N}$ occurred. These results are consistent with lack of significant effect of ISOPLUS ${ }^{\mathrm{TM}}$ supplementation on rumen $\mathrm{pH}$, ammonia concentration, and concentrations of straight-chain VFAs reported earlier for this study (Robinson et al., 1987b). They are also consistent with other studies in vivo where diets containing protein have been fed (Felix et al., 1980; Fieo et al., 1984).

This study does not suggest a stimulatory affect of isoacids on plasma concentration of somatotropin. However lack of influence is consistent with lack of difference in milk production reported previously for cows in the production study (de Visser \& Tamminga, 1987) as well as these cows (Robinson et al., 1987b).

More work is needed in this area and it would be of particular interest to measure digestibility in vivo and plasma hormone concentrations under conditions where supplementation with isoacids to practical diets significantly increased productivity, conditions not the case in reported in vivo studies, including this study.

\section{Acknowledgements}

We thank Mr C. van der Koelen for preparation of markers, organization of task allocation and disposition of samples; Ms F. Krol-Kramer, Mr R. Ketelaar, and Ms J. Vroons for collecting samples; and Mr R. Terluin and his crew for care of the cows. We also thank Ms J. Hoekstra (Institute TNO for Mathematics, Wageningen) for statistical advice. This research was funded in part by the Health and Nutrition Research Division, Eastman Chemicals Division, Eastman Kodak Company, Rochester, NY, USA. PHR was in receipt of a Fellowship from the Dutch Ministry of Agriculture and Fisheries. 


\section{References}

Bentley, O. G., R. R. Johnson, T. V. Hershberger, J. H. Cline \& A. L. Moxon, 1955. Cellulolytic-factor activity of certain short-chain fatty acids for rumen microorganisms in vitro. Journal of Nutrition 57: 389-400.

Brondani, A. V. \& R. M. Cook, 1985. Effects of isoacids on rumen fermentation and plasma hormone levels in sheep. Report on the 18th Conference on Rumen Function (Chicago), p. 39.

Bryant, M. P., 1973. Nutritional requirements of the predominant rumen cellulolytic bacteria. Federation Proceedings, Federation of American Societies for Experimental Biology 32: 1809-1813.

Cline, T. R., U. S. Garrigus \& E. E. Hatfield, 1966. Addition of branched-and strait-chain volatile fatty acids to purified lamb diets and effects on utilization of certain dietary components. Journal of Animal Science 25: 734-739.

Felix, A., R. M. Cook \& J. T. Huber, 1980. Effect of feeding isoacids with urea on growth and nutrient utilization by lactating cows. Journal of Dairy Science 63: 1943-1946.

Fieo, A. G., T. F. Sweeney, R. S. Kensinger \& L. D. Muller, 1984. Metabolic and digestion effects of the addition of ammonium salts of volatile fatty acids to the diets of cows in early lactation. Journal of Dairy Science 67 (Suppl. 1): 117.

Firkins, J. L., L. L. Berger, G. C. Fahey \& N. R. Merchen, 1984. Ruminal nitrogen degradability and escape of wet and dry distillers grains and wet and dry corn gluten feeds. Journal of Dairy Science 67: 1936-1944.

Firkins, J. L., L. L. Berger \& G. C. Fahey, 1985. Evaluation of wet and dry distillers grains and wet and dry corn gluten feeds for ruminants. Journal of Animal Science 60: 847-860.

Gorosito, A. R., J. B. Russell, \& P. J. Van Soest, 1985. Effect of carbon-4 and carbon-5 volatile fatty acids on digestion of plant cell wall in vitro Journal of Dairy Science 68: 840-847.

Hart, I. C., J. A. Bines \& S. V. Morant, 1980. The secretion and metabolic clearance rates of growth hormone, insulin and production in high- and low-yielding cattle at four stages of lactation. Life Sciences 27: 1829-1847.

Hartnell, G. F., L. D. Satter, 1979. Determination of rumen fill, retention time and ruminal turnover rates of ingesta at different stages of lactation in dairy cows. Journal of Dairy Science 48: 381-392.

Hemsley, J. A. \& R. J. Moir, 1963. The influence of higher volatile fatty acids on the intake of urea-supplemented low quality cereal hay by sheep. Australian Journal of Agricultural Research 14: 509-514.

McDonald, P., 1982. The effect of conservation processes on the nitrogenous components of forages. In: D. J. Thomson, D. E. Beever \& R. G. Gunn (Ed.). Forage Protein in Ruminant Animal Production. Occasional Publication 6, British Society of Animal Production, p. 41-49.

Meyer, J. H. F., S. I. van der Walt \& H. M. Schwartz, 1986. The influence of diet and protozoal numbers of the breakdown and synthesis of protein in the rumen of sheep. Journal Animal Science 62: 509-520.

Papas, A. M., S. R. Ames, R. M. Cook, C. J. Sniffen, C. E. Polan \& L. E. Chase, 1984. Production responses of dairy cows fed diets supplemented with ammonium salts of Iso C-4 and C-5 acids. Journal of Dairy Science 67: 276-293.

Peel, C. J., T. J. Fronk, D. E. Bauman \& R. C. Gorewit, 1983. Effect of exogenous growth hormone in early and late lactation on lactational performance of dairy cows. Journal of Dairy Science 66: 776782.

Pierce-Sandner, S. B., A. M. Papas, J. A. Rogers, T. F. Sweeney, K. A. Cummins, H. R. Conrad \& L. D. Muller, 1985. Supplementation of dairy cows diets with ammonium salts of volatile fatty acids. Journal of Dairy Science 68: 2895-2907.

Robinson, P. H. \& C. J. Sniffen, 1985. Forestomach and whole tract digestibility for lactating dairy cows as influenced by feeding frequency. Journal of Dairy Science 68: 857-867.

Robinson, P. H., J. G. Fadel \& S. Tamminga, 1986a. Evaluation of mathematical models to describe neutral detergent residue in terms of its susceptability to degradation in the rumen. Animal Feed Science and Technology 15:249-271.

Robinson P. H., S. Tamminga \& A. M. Van Vuuren, 1986b. Influence of declining level of feed intake and varying the proportion of starch in the concentrate on rumen fermentation in dairy cows. Livestock Production Science 15: 173-189. 
Robinson, P. H., S. Tamminga \& A. M. Van Vuuren, 1987a. Influence of declining level of feed intake and varying the proportion of starch in the concentrate on milk production and whole tract digestibility in dairy cows. Livestock Production Science 17: 19-35.

Robinson, P. H., S. Tamminga \& A. M. Van Vuuren, 1987b. Influence of wet vs. dry by-product ingredients and addition of branched chain volatile fatty acids and valerate to dairy diets. 2 . Rumen fermentation and milk production. Netherlands Journal of Agricultural Science 35: 447-458.

Robinson, P. H., S. Tamminga, \& A. M. Van Vuuren, 1987c. Influence of declining level of feed intake and varying the proportion of starch in the concentrate on rumen ingesta quantity, composition, and kinetics of ingesta turnover in dairy cows. Livestock Production Science 15: 37-62.

Russell, J. B. \& C. J. Sniffen, 1984. Effect of carbon-4 and carbon-5 volatile fatty acids on growth of mixed rumen bacteria in vitro. Journal of Dairy Science 67: 987-994.

Shaver, R. D., L. D. Satter \& N. A. Jorgensen, 1985. Ruminal retention time and fill in dairy cows: Effects of level of feed intake, forage physical form and forage fibre content. Report on the 18th Conference on Rumen Function, p. 45.

Stern, M. D., W. L. Blake, S. M. Hannah, A. Ruberti \& D. E. Otterby, 1985. Influence of branched chain volatile fatty acids on fiber digestion in continuous culture of rumen contents. Journal of Animal Science 59 (Suppl. 1): 449.

Tamminga, S. C., J. van der Koelen \& A. M. Van Vuuren, 1979. Effect of the level of feed intake on nitrogen entering the small intestine of dairy cows. Livestock Production Science 6: 255-262.

Umunna, N. N., T. Klopfenstein \& W. Woods, 1975. Influence of branched-chain volatile fatty acids on nitrogen utilization by lambs fed urea containing high roughage rations. Journal of Animal Science 40: 523-529.

Visser, H. de \& S. Tamminga, 1987. Influence of wet vs. dry by-product ingredients and addition of branched chain volatile fatty acids and valerate to dairy diets. 1. Feed intake, milk production and milk composition. Netherlands Journal of Agricultural Science 35: 163-175. 